\title{
Komunikasi sosial pemerintah dalam penyebaran informasi perbatasan Negara Indonesia dan Timor Leste
}

\author{
Kristin Engjelima Julwinda Nomleni ${ }^{1}$, Suwandi Sumartias ${ }^{2}$, Wawan Setiawan ${ }^{3}$ \\ 1,2,3 Universitas Padjadjaran, Bandung, Indonesia
}

\begin{abstract}
ABSTRAK
Tindakan pelanggaran perjanjian bilateral tahun 2005 oleh masyarakat Timor Leste memasuki lahan Naktuka sebagai area netral di antara perbatasan kedua negara, menimbulkan kecemasan dan mendorong masyarakat Netemnanu Utara (Indonesia) untuk mengambil tindakan anarkis. Sebagai antisipasi, diperlukan peran pemerintah Indonesia untuk menjalin komunikasi dengan masyarakat perbatasan melalui lembaga terkait, khususnya Badan Pengelola Perbatasan (BPP) Kabupaten Kupang yang bertanggung jawab mengurus wilayah perbatasan negara di wilayah Kabupaten Kupang. Penelitian ini bertujuan untuk mengetahui komunikasi sosial antara pihak BPP Kabupaten Kupang dengan masyarakat Netemnanu Utara berdasarkan jenis, proses, tahapan penerimaan informasi oleh masyarakat, dan karakteristik masyarakat Netemnanu Utara dalam mengadopsi informasi mengenai persoalan tersebut. Metode penelitian menggunakan kualitatif dengan pendekatan studi kasus. Hasil penelitian menunjukkan bahwa komunikasi sosial antara masyarakat dan pihak pemerintah daerah dengan pendekatan sosial budaya, selain itu adanya keputusan pemerintah pusat sebelumnya yang menyetujui penerapan perjanjian traktat 1904 bersama pihak Timor Leste menjadikan komunikasi sosial pemerintah gagal dan menimbulkan penolakan masyarakat karena dianggap tidak sesuai dengan sejarah hidup masyarakat Netemnanu Utara. Penelitian ini menyimpulkan, pemerintah menggunakan beragam jenis dan proses komunikasi sesuai situasi dan karakter masyarakat Netemnanu Utara. Penerimaan masyarakat atas inovasi atau kebaruan informasi terjadi dalam 3 tahap yaitu pengetahuan, persuasi dan tahap pengambilan keputusan. Tahap implementasi dan konfirmasi tidak berlanjut, karena masyarakat menilai minimnya pengetahuan pemerintah, tidak pernah dilibatkan, dan kesepakatan tersebut bertentangan dengan unsur budaya masyarakat perbatasan. Saran, pemerintah pusat maupun daerah sebaiknya selalu melibatkan masyarakat dalam setiap pengambilan keputusan berkaitan dengan batas wilayah antara kedua negara, sebelum melakukan kesepakatan untuk menghindari kegagalan komunikasi dan meminimalisir konflik.
\end{abstract}

Kata-kata Kunci: Komunikasi sosial; pemerintah; penyebaran informasi; perbatasan; negara

\section{Government social communications in spreading Indonesia and East Timor State Border information}

\begin{abstract}
East Timorese violated a bilateral agreement in 2005 by entering Naktuka land, a neutral area between the borders of the two countries, causing anxiety and anarchist action by the people of North Netemnanu (Indonesia). As anticipation, the role of the Indonesian Government is to establish communication with the border community through related institutions, specifically the Kupang Regency Border Management Agency $(B P P)$, which is responsible for managing the country's border areas in the Kupang Regency. This study aims to determine social communication between the BPP Kupang Regency with the people of North Netemnanu based on the type, process, stages of information received by the community, and the characteristics of the North Netemnanu community in adopting information about the problem. The research method uses qualitative with a case study approach. The results show that social communication between the community and the local Government with a socio-cultural approach; Decision of the previous central Government to approve the application of the 1904 treaty with the Timor Leste party, has failed and cause community rejection because it is not in line with the history of life North Netemnanu community. This study concludes that the Government uses various types and processes of communication according to the situation and character of the people of North Netemnanu. Public acceptance of innovation or newness of information occurs in 3 stages, namely: knowledge, persuasion, and decision making. The implementation and confirmation phase has ceased because the community considered that the Government lacks in knowledge, and the agreement was contrary to the cultural elements of the border communities. The suggestion proposed that the central and regional governments should always involve the community in every decision making related to the boundaries between the two countries, before agreeing in a tract to avoid communication failures and to minimize conflict.
\end{abstract}

Keywords: Social communication; government; information dissemination; border; country

Korespondensi: Kristin Engjelima Julwinda Nomleni, S.IKom. Universitas Padjadjaran. Jl. BandungSumedang KM. 21, Jatinangor, Sumedang, 45363.Email: kristin18002@mail.unpad.ac.id 


\section{PENDAHULUAN}

Sejak tahun 2006 wilayah demarkasi area zona bebas Naktuka dengan luas wilayah 1.069 ha ini sudah diolah lahannya dan dijadikan tempat tinggal oleh masyarakat yang berasal dari negara Timor Leste dengan jumlah 65 kepala keluarga. Hal inilah yang selama beberapa tahun terakhir menjadi pemicu timbulnya konflik di wilayah perbatasan, tindakan masyarakat Timor Leste terkhususnya masyarakat Citrana dinilai sebagai tindakan pelanggaran atas kesepakatan bersama oleh kedua belah pihak yaitu perjanjian sementara atau provisional agreement pada tahun 2005 di pulau Bali (Indonesia).

Tindakan agresif dilakukan pula oleh pemerintah Timor Leste dengan membangun kantor imigrasi pada akhir tahun 2008 dan kantor Kementerian Pertanian pada pertengahan 2009. Beberapa bangunan permanen milik Timor Leste telah berdiri di Dusun Naktuka diantaranya kantor pertanian, balai pertemuan, gudang dolog dan tempat penggilingan padi. Pemerintah Timor Leste juga membangun saluran irigasi dan jalan (Gumilar, 2017).

Peristiwa sengketa lahan Naktuka mengakibatkan masyarakat desa Netemnanu Utara Kecamatan Amfoang Timur Kabupaten Kupang (Indonesia), yang berbatasan langsung dengan Distrik Oekusi Timor Leste merasa resah dan cemas serta geram karena warga Timor Leste terus membangun pemukiman di wilayah zona bebas tersebut. Masyarakat Netemnanu Utara beranggapan bahwa jika terus dibiarkan tanah sengketa itu lama kelamaan akan diklaim sebagai tanah atau wilayah milik Timor Leste (Kusumadewi, 2016; Utama, 2016) Terlihat potensi lahan naktuka yang sangat baik untuk pertanian dan anggapan terhadap tindakan penyelesaian masalah perbatasan antara kedua negara oleh pemerintah dirasakan belum sesuai harapan masyarakat, hal ini mengakibatkan masyarakat dan tokoh adat yang ada di wilayah perbatasan berkehendak melakukan tindakan yang bersifat anarki kepada warga Timor Leste (perang) bahkan ingin menduduki wilayah area netral Naktuka (Biliocta, 2016).

Berdasarkan peristiwa tersebut maka komunikasi menjadi cara yang perlu diterapkan secara tepat baik antara pihak pemerintah dan masyarakat Netemnanu utara terhadap tindakan lanjut maupun upaya pemerintah, dalam mengatasi permasalahan tapal batas area zona bebas secara jelas, sehingga dapat mengantisipasi tindakan-tindakan negatif yang hendak dilakukan masyarakat melalui penyampaian atau penyebaran informasi oleh Badan Pengelola Perbatasan Daerah Kabupaten Kupang kepada masyarakat di wilayah perbatasan terkait permasalahan sengketa lahan Natuka.

Masyarakat itu sendiri memiliki hak dalam mendapatkan sebuah informasi dari pihak-pihak atau pemangku kebijakan, hal ini terdapat dalam UU Nomor 14 Tahun 2008 tentang kebebasan memperoleh informasi publik (Setiaman, Sugiana \& Narotama, 2013), sehingga masyarakat perbatasan juga memiliki hak memperoleh informasi yang jelas akurat dan berimbang. Komunikasi sosial adalah salah satu bentuk komunikasi yang lebih intensif, dimana komunikasi dapat terjadi secara langsung antara komunikator dengan komunikan itu sendiri, sehingga situasi komunikasi bersifat 2 arah serta lebih diarahkan kepada pencapaian suatu situasi integrasi sosial (Susanto, 1985) dimana akan terjadi berbagai pembahasan masalah yang diaktualisasikan.

Komunikasi sosial sebagai bentuk komunikasi oleh BPPD Kabupaten Kupang dalam menyebarluaskan informasi tentang persoalan tapal batas tersebut sangat penting untuk perkembangan maupun ketahanan wilayah NKRI di perbatasan khususnya pada masyarakat di wilayah terdepan negara Indonesia bagian timur ini, sesuai dengan fungsi komunikasi sosial yaitu mengisyaratkan bahwa komunikasi penting untuk membangun konsep diri, untuk kelangsungan hidup, aktualisasi diri, memperoleh kebahagiaan, terhindar dari tekanan dan ketergantungan antara lain untuk menghibur dan memupuk hubungan dengan orang lain. Terkait penyelesaian masalah ini fungsi komunikasi sosial dalam menyebarluaskan informasi oleh Badan Pengelola Perbatasan Daerah Kabupaten Kupang dapat membuat masyarakat melangsungkan hidupnya dengan nyaman, bahagia tanpa tertekan oleh masalah batas wilayah negara Naktuka yang diduduki pihak warga Timor Leste, dan meminimalisir timbulnya konflik di wilayah tapal batas area zona bebas Naktuka antara negara Indonesia dan Timor Leste.

Berdasarkan berbagai penjelasan di atas, peneliti pun melakukan penelitian pada Badan Pengelola Perbatasan Daerah yang berada 
di wilayah Kabupaten Kupang. Penelitian dilakukan untuk mengidentifikasi sejauh mana proses penyebaran informasi melalui komunikasi sosial yang dilakukan terkait persoalan titik batas wilayah netral (freezone) Naktuka antara Indonesia dan Timor Leste, dalam pemberian informasi terhadap tindakan pemerintah menyelesaikan masalah batas negara sehingga dapat mengantisipasi hal-hal negatif yang hendak dilakukan oleh masyarakat perbatasan.

Teori yang digunakan dalam penelitian ini adalah teori Difusi Inovasi yang dicetuskan oleh Everett M. Rogers dengan empat asumsi dasarnya yaitu inovasi, saluran komunikasi, jangka waktu dan sistem sosial (1995). Selain itu tahapan adopsi inovasi dan karakteristik adopter terkait komunikasi sosial pemerintah dalam menyebarkan informasi tentang persoalan tapal batas kepada masyarakat. Maka yang menjadi rumusan masalah dalam penelitian ini yaitu "Bagaimana Komunikasi Sosial Pemerintah dalam Penyebaran Informasi Perbatasan Negara Indonesia dan Timor Leste (Studi Kasus Pada Badan Pengelola Perbatasan Daerah Kabupaten Kupang-Nusa Tenggara Timur)?". Tujuan dari penelitian ini yaitu (1). Untuk mengetahui jenis komunikasi sosial yang terjadi antara pihak BPP Kabupaten Kupang dan masyarakat Netemnanu Utara (2) untuk mengetahui proses terjadinya komunikasi secara sosial oleh Badan Pengelola Perbatasan Daerah Kabupaten Kupang dalam menyebarkan informasi perbatasan pada masyarakat Netemnanu Utara, (3) untuk mengetahui tahap penerimaan informasi masyarakat Netemnanu Utara dari penyebaran informasi yang dilakukan BPP Kabupaten Kupang, (4) untuk mengetahui karakteristik dari masyarakat Netemnanu Utara dalam mengadopsi informasi persoalan perbatasan antara negara Indonesia dan Timor Leste dari BPP Kabupaten Kupang-NTT.

\section{METODE PENELITIAN}

Penelitian ini menggunakan metode atau pendekatan kualitatif dengan jenis studi kasus. Studi kasus merupakan penelitian di mana peneliti menggali suatu fenomena tertentu (kasus) dalam suatu waktu dan kegiatan (program, proses, institusi, atau kelompok sosial) serta mengumpulkan informasi secara terinci dan mendalam dengan menggunakan berbagai prosedur pengumpulan data selama periode tertentu (Creswell, 2007).

Peneliti menggunakan metode kualitatif studi kasus agar hasil penelitian yang didapat di lapangan lebih mendalam terkait kasus permasalahan lahan perbatasan sebagai area zona bebas yaitu Naktuka yang kini menjadi pemicu konflik di wilayah perbatasan antara negara Indonesia dan Timor Leste. Kejadian ini mengharuskan peran dan sikap pemerintah dalam menyebarkan informasi kepada masyarakat Netemnanu Utara yang merasa cemas, geram, dan hendak melakukan tindakan anarki karna sikap masyarakat Timor Leste, melalui komunikasi secara sosial oleh BPPD di Kabupaten Kupang Nusa Tenggara Timur, agar dapat mengantisipasi hal negatif tersebut sebagai sebuah kasus dalam penelitian ini. Untuk itu peristiwa ini mendorong peneliti untuk mencari narasumber yang multisource sebagai salah satu karakteristik studi kasus, sehingga dapat digunakan sebagai pembanding dalam tindakan komunikasi sosial untuk menyebarkan informasi kepada masyarakat Indonesia di wilayah perbatasan antara Indonesia dan Timor Leste terkhususnya pada wilayah desa Netemnanu Utara.

Adapun subjek penelitian atau key informant dalam penelitian ini yaitu Badan Pengelola Perbatasan Kabupaten Kupang dalam melaksanakan aktivitas baik di kantor maupun kunjungan kerja ke daerah atau wilayah perbatasan, dalam mengkomunikasikan secara sosial untuk menyebarkan informasi titik batas negara Indonesia dan Timor Leste kepada masyarakat Netemnanu Utara di wilayah tapal batas NKRI berdasarkan kriteria penelitian sehingga didapati 2 orang key informant dari unsur pemerintahan, dan untuk mendukung pernyataan yang disampaikan oleh pihak pemerintah sebagai key informant, peneliti juga menggunakan informan pendukung yaitu masyarakat sesuai dengan kriteria penelitian sebagai penerima kebaruan informasi terkait penyelesaian masalah perbatasan yang dilakukan pemerintah yaitu seorang tokoh adat masyarakat perbatasan.

Penelitian dilakukan selama tiga bulan. Adapun Lokasi penelitian peneliti adalah Badan Pengelola Perbatasan Daerah yang berada di wilayah Kabupaten Kupang, yang dispesifikasikan pada bidang yang mengelola batas negara yaitu Pengelolaan Batas Negara di 
Oelamasi Kabupaten Kupang - Nusa Tenggara Timur.

Alasan mendasar peneliti melakukan penelitian di lokasi tersebut dikarenakan Lembaga BPP Kabupaten Kupang bidang Badan Pengelolaan Batas Negara merupakan pihak pemerintah di tingkat daerah yang secara khusus menyebarkan infromasi terkait titik batas wilayah perbatasan wilayah Kabupaten Kupang yaitu daerah perbatasan antara Indonesia dan Timor Leste.

Penelitian secara kualitatif menjadikan instrumen penelitian adalah peneliti yang melakukan penelitiannya, sehingga peneliti juga diharuskan untuk mendapatkan validitas terhadap kemampuan peneliti. Validasi terhadap peneliti, seperti pemahaman terhadap metode penelitian kualitatif, penguasaan wawasan mengenai bidang yang akan diteliti, kesiapan secara personal peneliti untuk berada di tengahtengah objek penelitian secara logika maupun akademik seorang peneliti (Sugiono, 2009).

Seorang peneliti kualitatif yang tentunya adalah human instrument, harus bisa menetapkan atau menempatkan fokus penelitian, memilih informan yang sesuai sebagai sumber, memperoleh data, melakukan pengumpulan hasil data, menilai berbagai kualitas data yang didapatkan, menganalisis data lapangan serta menafsirkan data yang didapat dan membuat atau menarik kesimpulan atas hasil temuannya (Sugiono, 2009).

Peneliti menggunakan teknik penentuan terhadap informan secara purposive sampling, dimana informan yang dipilih disesuaikan dengan karakteristik informan. Informan dalam penelitian ini yaitu karyawan di BPP Kabupaten Kupang yang mengetahui secara benar mengenai persoalan tapal batas area zona bebas Naktuka antara negara Indonesia dan Timor Leste, sering juga melakukan kunjungan di wilayah perbatasan serta turut melakukan aktivitas komunikasi dengan masyarakat. Selain itu masyarakat yang paham terkait persoalan perbatasan dan mengikuti agenda atau kegiatan yang dilakukan serta berinteraksi langsung dengan pihak BPP Kabupaten Kupang.

Teknik pengumpulan data penelitian adalah observasi pasif, wawancara secara mendalam dan melakukan dokumentasi. Observasi merupakan teknik pengumpulan data dengan melakukan pengamatan pada lokasi yang menjadi pusat penelitian. Observasi pasif yaitu serangkaian tindakan yang dilakukan peneliti dalam mengamati setiap tindakan atau aktivitas individu yang mendukung data penelitian, yang terlibat dalam peristiwa yang sama namun peneliti tidak terlibat dalam aktivitas yang dilakukan oleh individu yang sedang diamati. Peneliti juga mencoba mengumpulkan berbagai data sebanyak-banyaknya melalui observasi secara pasif dengan mengamati aktivitas BPP Kabupaten Kupang di kantor dan kunjungan ke wilayah perbatasan tanpa terlibat dalam rangkaian kegiatan yang dilakukan.

Wawancara mendalam (In-depth Interview)adalah proses memperolehketerangan untuk tujuan penelitian dengan cara tanya jawab antara pewawancara dengan responden atau orang yang diwawancarai, dengan atau tanpa menggunakan pedoman (guide) wawancara. Untuk mendapatkan hasil yang sesuai kebutuhan penelitian, peneliti secara mendalam melalui pertanyaan yang diajukan terhadap narasumber saat melakukan wawancara, tidak hanya berpanduan pada teks pertanyaan tapi peneliti juga mengembangkan pertanyaan lainnya yang ditanyakan selama wawancara untuk mendapatkan hasil informasi yang lebih tajam serta dapat dipertanggungjawabkan. Studi pustaka yaitu kegiatan mendapatkan informasi yang relevan dari pemberitaan media maupun kajian-kajian literatur yang mendukung dalam mengkaji masalah penelitian. Peneliti mencari literatur dan informasi dari media terkait kegiatan atau aktivitas BPP Kabupaten Kupang kepada masyarakat khususnya dalam interaksi yang dilakukan, kemudian ditelaah dan disesuaikan dengan hasil wawancara untuk mendapatkan fakta yang sesuai.

Analisis data dalam penelitian ini menggunakan Model Interaktif (Miles \& Huberman, 1984). Analisis model ini terdiri dari 3 tahapan yakni reduksi data, penyajian data, dan penarikan kesimpulan. Peneliti melakukan pemilahan atau verifikasi data sebelumnya untuk mengecek setiap tingkat kebenaran data lapangan yang dianalisis, sehingga dapat dilakukan penyusunan atau penyajian data dan kemudian dilakukan penarikan kesimpulan yang dapat dipergunakan untuk mengambil tindakan.

\section{HASIL DAN PEMBAHASAN}

Artikel ini melihat bagaimana komunikasi 
memiliki peran dalam konflik (Wani, 2011; Kolne, 2014; Mutti, 2014; Raharjo, 2014). Dalam konteks ini, jenis komunikasi sosial yang dilakukan pemerintah dengan masyarakat perbatasan adalah komunikasi sosial (Rahman \& Sjoraida, 2017). Komunikasi sosial menjadi kegiatan pertukaran dan penerimaan pesan yang selama ini dilakukan antara pemerintah dan masyarakat Netemnanu Utara di wilayah perbatasan, untuk melakukan penyebaran informasi mengenai kegiatan pemerintah, terkait dengan permasalahan perbatasan dan kegiatan yang hendak dilakukan dalam membantu pembangunan di wilayah perbatasan. Badan Pengelola Perbatasan Daerah di Kabupaten Kupang sebagai pihak pemerintah daerah yang memiliki pelayanan administrasi kepada masyarakat sesuai tupoksi yang berlaku tentu berkaitan dengan kehidupan masyarakat yang berada di titik batas negara.

Berdasarkan hasil penelitian di lapangan dengan merujuk pada jenis komunikasi sosial dari sudur pandang Hendropuspito dalam karyanya yaitu "Sosiologi Sistematik" (Hendropuspito, 1989) terdapat dua jenis komunikasi sosial yang selama ini diperankan oleh pemerintah yaitu: (a) Komunikasi secara langsung, atau komunikasi secara tatap muka (face to face). Dalam melakukan proses komunikasi secara sosial dalam melakukan penyebaran informasi dilakukan melalui pertemuan secara langsung dengan masyarakat perbatasan. Agar ketika pesan disampaikan masyarakat memahami setiap penyampaian dari pihak BPPD Kabupaten Kupang serta BPPD Kabupaten Kupang juga secara langsung mendapat respons dari masyarakat terkait informasi yang dikomunikasikan dan terjalinlah komunikasi dengan suasana yang menunjukkan kekeluargaan dan rasa saling percaya diantara kedua belah pihak pelaku komunikasi. (b) Komunikasi bebas (nonorganik) formalitas tidak menjadi patokan yang bersifat mengikat, yang menjadi patokan atau ikatan adalah kode atau nilai sosio-kultural. Komunikasi seperti inilah yang biasanya terjadi saat BPPD Kabupaten Kupang saat bertemu dengan masyarakat di wilayah titik batas negara, dimana setiap informasi disampaikan dengan kondisi yang tidak mengikat secara formalitas namun lebih mengarah pada aturan sosio maupun kultural yang ada.

Melalui penyesuaian dengan nuansa seperti ini, masyarakat perbatasan menjadi lebih paham, menerima maupun merespons setiap penyebaran atau amanat yang disampaikan oleh BPP Kabupaten Kupang, dalam menyebarkan informasi untuk mengikuti atau menyesuaikan perjanjian traktat tahun 1904 yang disampaikan kepada masyarakat langsung mendapat penolakan.

Proses komunikasi sosial pemerintah kepada masyarakat selalu memperhatikan unsur keadaan masyarakat terkhususnya unsur budaya. BPP kabupaten kupang sebagai agent of change yang mendapat mandat sebagai mediasi pemerintah pusat maupun untuk menyebarkan informasi mengenai persoalan tapal batas, terkait keputusan menyesuaikan atau menerapkan dengan perjanjian traktat tahun 1904 kepada masyarakat sesuai kesepakatan kedua belah pihak pemerintah baik Indonesia maupun Timor Leste menghasilkan penolakan dari masyarakat yang terus berlanjut. Kesepakatan mengikuti perjanjian traktat 1904 dianggap sebagai sebuah kebaruan informasi, dikarenakan ketidaksesuaian dan keterbiasaan masyarakat Amfoang (Netemnanau Utara) hidup di wilayah perbatasan menurut sejarah sebelum zaman penjajahan terkait batas wilayah Naktuka di antara kedua belah pihak negara (Wawancara dengan Tokoh adat/Raja Amfoang, Robby Manoh). Inovasi sendiri adalah sebuah gagasan, tindakan atau barang dan dianggap sebagai kebaruan oleh seseorang. Dalam hal ini, kebaruan sebuah inovasi dapat diukur secara subjektif sesuai pandangan seseorang menerimanya. Jika sebuah ide dianggap sebagai suatu kebaruan oleh individu maka ia adalah hal tersebut merupakan inovasi bagi orang tersebut. Suatu konsep baru yang terdapat dalam ide yang inovatif tidak selamanya atau harus sebagai sesuatu yang baru (Rogers, 1995).

Apabila disesuaikan dengan penjelasam di atas, keputusan mengikuti perjanjian traktat 1904 dianggap sebagai suatu informasi yang baru atau inovasi di kehidupan masyarakat perbatasan, Hal ini dikarenakan komunikasi antara pihak pemerintah pusat terkhususnya dengan masyarakat perbatasan terkait kesepakatan mengikuti perjanjian traktat 1904 dan keputusan itu dianggap tidak relevan dengan sejarah maupun budaya masyarakat di titik batas negara RI--RDTL. Rogers mengatakan terdapat empat faktor terkait proses keputusan sebuah inovasi. Antara lain seperti change 
of agent, struktur sosial, opinion leaders dan sistem norma.

Berdasarkan empat faktor tersebut, BPP Kabupaten Kupang sebagai penyebar informasi dan mediasi pemerintah pusat atau agent of change melakukan penyesuaian dengan kondisi sosial budaya masyarakat di perbatasan dalam menyebarkan informasi. Selain itu, struktur sosial pada masyarakat perbatasan sangat melekat dan kuat, masyarakat selalu menghormati para turunan raja sebagai pemimpin mereka seperti raja Amfoang, Vetor sebagai tokoh adat serta memiliki pengaruh yang besar dalam pengambilan suatu keputusan dan budaya yang masih sangat kental.

Masyarakat biasanya lebih mengikuti penyampaian dari raja Amfoang, selain itu masyarakat asli dari wilayah Amfoang yang hidup merantau untuk melanjutkan sekolah kemudian berhasil dan kembali akan memiliki posisi penghargaan diri yang cukup tinggi meski pada dasarnya terdapat aturan atau norma yang mengikuti sistem kerajaan, hal seperti ini dapat dilihat dari kepala dinas BPPD Kabupaten Kupang yang merupakan putra asli daerah Amfoang, sehingga ketika menyebarkan informasi maupun melakukan aktivitas di wilayah perbatasan, masyarakat memberikan respon positif karena dianggap disampaikan oleh putra daerah (wawancara dengan Kepala Badan Pengelola Perbatsan Kabupaten Kupang, Kain Maus. Tanggal 08 Februari 2017). Tapi perlu dipahami bahwa masyarakat juga pada umumnya akan mengikuti atau mendengarkan sebuah informasi bila disepakati maupun disebarluaskan lagi oleh Raja dan Vetor yang merupakan opinion leader di wilayah perbatasan meski disampaikan oleh penduduk asli dari wilayah perbatasan (Wawancara dengan Tokoh adat, Robby Manoh. 15 Februari 2017).

Kemampuan berbahasa daerah pimpinan BPPD Kabupaten Kupang sebagai putra asli Amfong mendorong masyarakat untuk ikut serta dalam pertemuan yang dilakukan oleh BPP Kabupaten Kupang, dimana pertemuan ini biasanya dilakukan di balai pertemuan masyarakat perbatasan. Selain adanya unsur penyesuaian untuk berkomunikasi dengan masyarakat dengan memperhatikan sistem nilai dan norma yang berlaku.

Saluran komunikasi yang biasanya menjadi konteks komunikasi sosial dalam penyebaran informasi yaitu saluran antar atau secara pribadi, sering diistilahkan juga sebagai saluran interpersonal. Biasanya pemerintah daerah atau BPP Kabupaten Kupang, melakukan pertemuan terlebih dulu dengan para opinion leader yaitu tokoh adat dan tokoh masyarakat dengan menggunakan pendekatan komunikasi secara interpersonal sebelum bertemu dengan masyarakat. Sistem komunikasi yang terjalin bersifat responsif atau terjadinya komunikasi 2 arah atau timbal balik. Masyarakat menerima informasi langsung kemudian memberikan tanggapan sehingga mudah dimengerti oleh kedua belah pihak baik pemerintah maupun masyarakat Netemnanu Utara. Penyebaran informasi yang dikomunikasikan secara sosial tentang perjanjian traktat 1904 yang menjadi kesepakatan pemerintah melalui BPP Kabupaten Kupang pada dasarnya dikontekskan dengan budaya masyarakat secara sosial kultural.

Adapun prosesnya, BPP Kabupaten Kupang melakukan pertemuan terlebih dahulu dengan tokoh adat maupun tokoh masyarakat. Selanjutnya para tokoh adat mengumpulkan masyarakat dan diadakan pertemuan antara pihak pemerintah, tokoh adat dan masyarakat di balai pertemuan, kemudian disampaikan keputusan mengikuti perjanjian traktat 1904. Namun informasi tersebut ditolak oleh raja, vetor maupun amaf-amaf sebagai opinion leader di wilayah perbatasan Netemnanu Utara, sehingga masyarakat pun ikut menolak penetapan perjanjian traktat tahun 1904 karena masyarakat menganggap tidak sesuai dengan nilai maupun budaya yang ada.

Masyarakat menganggap adanya ketidakseimbangan dalam keputusan tersebut, pemerintah dinilai tidak melibatkan atau berkomunikasi dengan masyarakat Netemnanu Utara terlebih dahulu dan wilayah netral Naktuka merupakan wilayah bagian Indonesia di Amfoang sejak adanya zaman kerajaan. Berkaitan dengan penetapan batas wilayah secara treaty 1904, warga menolak dengan anggapan tidak sah jika mengkuti kesepakatan buatan penjajah, dimana menurut sejarah perjanjian 1904 pada masanya dipergunakan untuk keuntungan bagi kedua bangsa penjajah yaitu Belanda dan Portugis dibidang perpolitikan atau bisnis, mereka melakukannya dengan membuat batas patok dan menghancurkan pilar yang menjadi batas kerajaan Amfoang saat Indonesia dijajah.

Peristiwa inilah yang menjadi alasan kuat 
bagi masyarakat Netemnanu Utara dimana masalah ini harus dikomunikasikan melalui pertemuan antara masyarakat Indonesia maupun Timor Leste, bukan dengan cara mensahkan perjanjian yang dibuat oleh penjajah, mereka menganggap bahwa kerajaan sudah ada sebelum datang para penjajah dan dinilai tidak relevan terhadap nilai atau unsur budaya yang semestinya. Artinya hal ini bertentangan dengan sistem norma yang ada, dimana sistem norma saling terkait dengan derajat kesesuaian (compatibility) suatu inovasi atau kebaruan informasi dengan nilai atau kepercayaan suatu masyarakat dalam sebuah sistem sosial (Rogers, 1995).

Perjanjian traktat 1904 merupakan bentukan hukum pada zaman penjajahan dan menjadi salah satu bagian dalam mencapai kesepakatan batas darat RI dengan RDTL, dimana pada tahun 2002 sampai 2005 dilaksanakan pada 3 level kesepakatan, salah satunya yaitu pada level Technical Sub-Commitee Border Demarcration and Regulation (TSC-BDR) dengan menggunakan 3 tahapan seperti definisi yaitu melakukan kesepakatan tentang titik, syarat, suatu definisi tertentu sebagai dasar penentuan batas, delineasi dengan menarik garis batas wilayah, dan demarkasi atau penetapan secara tegas mengenai batas sebuah wilayah di lapangan. Sehingga pada level kesepakatan inilah dilakukan perundingan batas wilayah dengan mengacu pada perjanjian treaty tahun 1904, dimana kedua tim perunding melakukan sebuah workplan dengan tujuan mencapai kesepakatan delineasi penarikan garis batas pada 30 juni 2003 jika memungkinkan dengan titik koordinat definitife, dimana wilayah Naktuka merupakan bagian wilayah yang belum mendapatkan titik batas secara jelas bagi kedua negara.

Peristiwa tindakan melanggar perjanjian oleh masyarakat Timor Leste sejak tahun 2006, dinilai sebagai tindakan pihak Timor Leste agar wilayah netral Naktuka manjadi bagian wilayah Timor Leste oleh masyarakat Amfoang dengan menetapkan treaty tahun 1904, dan adanya tanggapan terhadap pemerintah di pusat yang tidak memahami baik tentang sejarah batas wilayah dan dianggap mementingkan kepentingan tertentu, anggapan ini muncul dikarenakan tidak adanya keterlibatan atau melibatkan komunikasi mengenai kesepakatan treaty tahun 1904 antara BPPD Kabupaten
Kupang dengan masyarakat yang lebih mengetahui titik batas wilayah sesuai nilai dan sejarah sejak kerajaan masih ada, seharusnya disadari oleh pihak pemerintah pusat. Fungsi dan tugas yang selama ini dijalankan oleh BPPD Kabupaten Kupang hanya melakukan kegiatan sesuai penjabaran dari pemerintah pusat yang menjadi bagian tupoksi pemerintah daerah melalui sepuluh kegiatan pada bidang pengelolaan batas negara di BPPD Kabupaten Kupang.

Berdasarkan permasalahan tersebut, treaty tahun 1904 sebagai sebuah inovasi melalui komunikasi secara sosial tidak direspons atau diterima masyarakat, terdapat 5 karakteristik dari inovasi yang dapat mempengaruhi keputusan menurut Rogers:

Pertama yaitu keunggulan secara relatif, komunikasi secara sosial oleh pemerintah daerah yaitu BPPD Kabupaten Kupang dalam menyebarkan informasi dan juga mediasi pemerintah pusat dengan masyarakat perbatasan atas penyebaran informasi tentang kesepakatan perjanjian treaty 1904 tidak terdapat keunggulan relatif, dilihat dari tingkat kepuasaan masyarakat maupun keamanan.

Kedua yaitu kompatibilitas, yaitu dalam menyebarkan informasi oleh pihak BPPD Kabupaten Kupang selalu dilakukan penyesuaian terhadap sistem nilai atau norma yang berlaku agar masyarakat dapat memahami dan menerima informasi yang disampaikan melalui komunikasi sosial berdasarkan unsur budaya yang ada. Berbeda dengan penyebaran informasi pemerintah pusat kepada masyarakat yang di mediasi BPPD Kabupaten Kupang, mengenai resolusi terhadap masalah tapal batas mengenai kesepakatan menggunakan perjanjian traktat 1904 oleh kedua pemerintah, menjadikan kesepakatan yang langsung ditolak masyarakat Netemnanu Utara.

Komunikasi dalam menyebarkan informasi yang dilakukan pemerintah menjadi gagal atau ditolak oleh masyarakat dikarenakan kesepakatan tersebut tidak sesuai dengan sejarah wilayah perbatasan masyarakat Netemnanu Utara Kecamatan Amfoang Timur. Wilayah Naktuka merupakan bagian dari kerajaan Amfoang yang diyakini sudah ada dari zaman berlakunya kerajaan di Indonesia, saat diketahui bahwa wilayah perbatasan antara kedua negara ini disesuaikan dengan perjanjian traktat 1904 masyarakat langsung melakukan 
penolakan. Bagi masyarakat Netemnanu Utara perjanjian traktat 1904 merupakan perjanjian penjajah untuk memenuhi kepentingan penjajah di bidang keuntungan bisnis dan perpolitikan, bukan kesepakatan para raja baik itu Amfoang (RI) dengan Ambenu (RDTL).

Ketiga yaitu kerumitan, mengenai masalah tapal batas Naktuka, penyebaran informasi dengan menggunakan komunikasi secara sosial BPPD Kabupaten Kupang dengan menyepakati treaty 1904 dimengerti masyarakat namun karena perjanjian itu bertentangan sejarah dan budaya masyarakat di wilayah perbatasan. Keempat yaitu kemampuan untuk diujicobakan, kesepakatan kedua belah pihak pemerintah mengenai treaty 1904 sebagai landasan pengukuran batas wilayah negara, langsung ditolak oleh masyarakat. Berdasarkan ketiga karakteristik sebuah inovasi yaitu treaty 1904 di atas, dengan demikian treaty 1904 tidak dapat diujicobakan karena penerima informasi yaitu masyarakat perbatasan menolak secara langsung dan terus menerus dengan anggapan negatif terhadap pemerintah. Masyarakat menganggap bahwa kegiatan pemerintah pusat hanyalah untuk menghabiskan anggaran dan dinilai tidak peduli pada masalah perbatasan Naktuka karena pemerintah tidak melakukan komunikasi atau masyarakat dilibatkan dalam sebelum menyepakati keputusan tersebut. Masyarakat juga beranggapan bahwa pihak pemerintah Timor Leste dengan sengaja mengambil kesempatan saat itu untuk mendapatkan wilayah netral Naktuka dan masyarakat Timor Leste yang tetap mendiami wilayah tersebut sehingga hal ini dianggap penyelewengan atas perjanjian tahun 2003.

Terakhir yaitu kemampuan untuk diamati dari penyebaran informasi. Berdasarkan keputusan menyepakati treaty tahun 1904 yang langsung ditolak oleh masyarakat secara terus menerus hingga saat ini, hal ini menjadi sorotan kepada pihak pemerintah dalam negeri di tingkat pusat, serta pihak pemerintah dan masyarakat Timor Leste, karena hal ini dapat menjadi sebuah konflik yang tidak diinginkan oleh siapa pun di wilayah perbatasan antara kedua negara. Masyarakat maupun pemerintah daerah seperti Badan Pengelola Perbatasan Kabupaten Kupang yang tidak terlibat sama sekali dalam pengambilan keputusan dan komunikasi yang tidak terbangun antara masyarakat dan pihak pemerintah pusat dalam menyelesaikan persoalan perbatasan di wilayah Indonesia Timur yaitu Naktuka, dan kebaruan informasi mengikuti perjanjian traktat 1904 dinilai memberikan peluang kemenangan bagi pihak Timor Leste untuk mendapatkan wilayah netral tersebut.

Di lain pihak kegiatan pemerintah pusat dalam melakukan sosialisasi dan pengambilan data hanya oleh pegawai biasa. Hal ini membuat masyarakat menjadi tidak puas ketika menanyakan perihal masalah wilayah dengan jawaban yang penuh dengan ketidaktahuan maupun kepastian oleh pihak pemerintah pusat tersebut.

Tahap Penerimaan Informasi Masyarakat Perbatasan. Penyebaran informasi secara komunikasi sosial mengenai kesepakatan antara pemerintah pusat dan pihak Timor Leste dengan menetapkan treaty 1904 kepada masyarakat oleh BPPD Kabupaten Kupang melalui tahapan dalam mengambil keputusan bagi masyarakat untuk tidak maupun menerima informasi itu.

Roggers mengemukakan 5 tahapan berdasarkan proses dalam mengambil keputusan informasi atau inovasi, selanjutnya akan dipola dalam bentuk model sebagai tahapan dalam penerimaan maupun penyebaran informasi perjanjian traktat 1904 pada masyarakat Netemnanu Utara, dapat dilihat pada gambar 1.

Tahap pertama, tahap pengetahuan (knowledge). Beberapa sumber mengatakan tahap ini sebagai tahap "awareness", dimana tahap ini dinilai sebagai tahap penyebaran informasi tentang kebaruan informasi mengenai penyelesaian batas negara. Kegiatan komunikasi sosial dalam menyebarkan informasi menggunakan saluran komunikasi antarpersonal. Komunikasi ini dianggap paling efektif karena sesuai dengan keadaan masyarakat yang lebih menghargai adanya pertemuan secara langsung atau dinilai etis serta masyarakat dapat lebih memahami dan memberikan respons berkaitan dengan sebaran informasi yang dilakukan.

Hal inilah yang membuat BPP kabupaten untuk melakukan komunikasi secara sosial untuk menyampaikan informasi mengenai kesepakatan perjanjian traktat 1904 berkaitan dengan masalah wilayah Naktuka maupun dalam agenda kegiatan pemerintah di wilayah perbatasan. Berdasarkan kebiasaan yang dilakukan, khususnya mengenai penyebaran informasi kesepakatan perjanjian traktat 


\section{KONDSI AWAL}

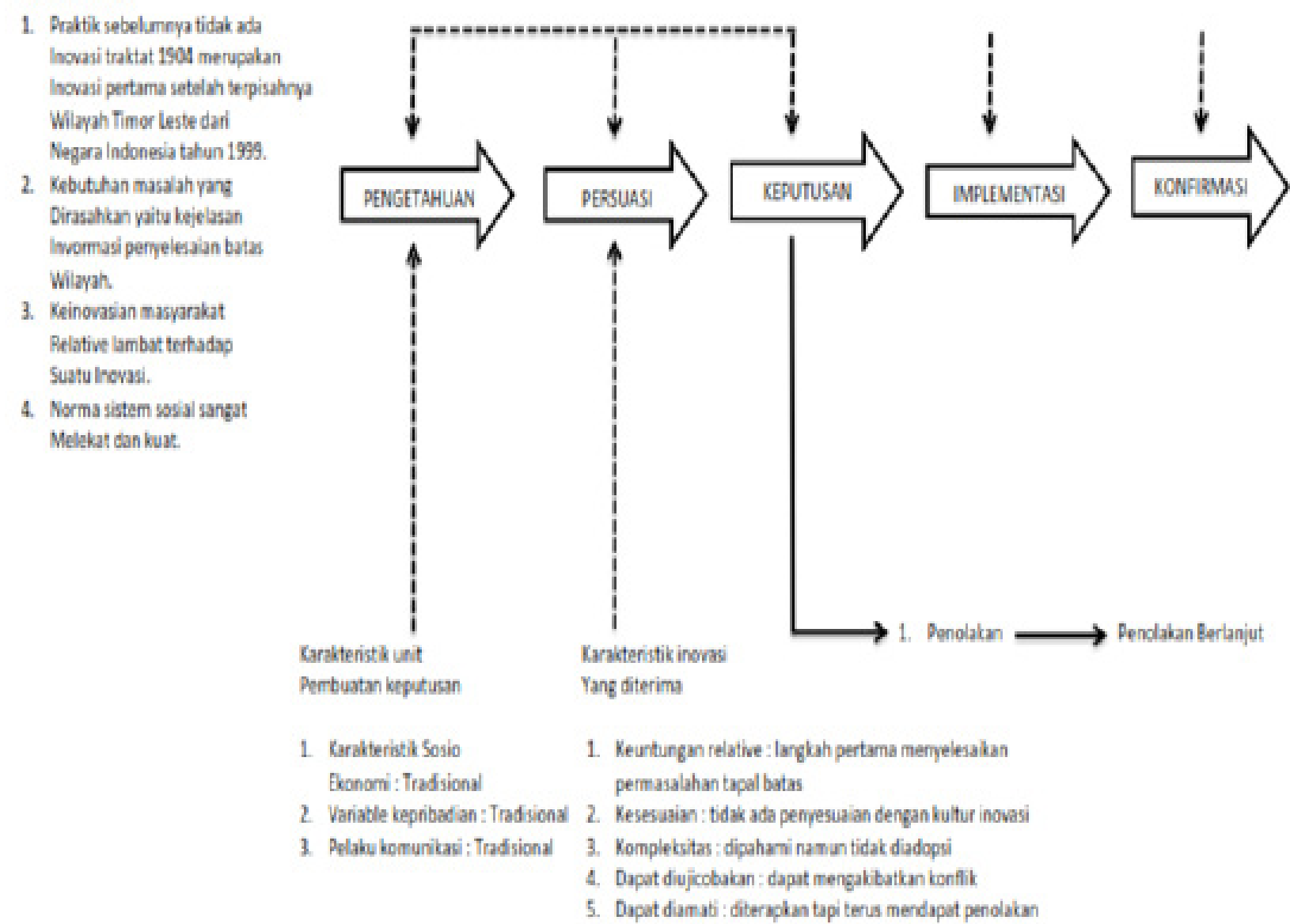

Sumber: Roggers, 1995

\section{Gambar 1 Model Tahapan Difusi Inovasi dalam Penyebaran Informasi Perbatasan pada Masyarakat} Netemnanu Utara

1904, pemerintah akan berkomunikasi dengan pemerintah daerah di wilayah Naktuka kemudian mereka akan menyampaikan pada tokoh-tokoh masyarakat seperti tokoh adat lalu diadakan pertemuan di balai desa untuk menyebarkan atau menginformasikan perjanjian traktat 1904 secara bertatapan langsung antara kedua belah pihak baik itu pemerintah maupun masyarakat.

Tahapan pengetahuan berlangsung dengan pemberian pengetahuan untuk menyampaikan informasi melalui pemerintah daerah setempat kemudian kepada tokoh adat dan dilakukannya komunikasi dua arah dalam pertemuan dengan masyarakat perbatasan dan BPPD Kabupaten Kupang melalui komunikasi secara sosial yang diterapkan.
Karakteristik masyarakat Netemnanu Utara diposisikan menjadi pengadopsi atau adopter kebaruan informasi melalui penyebarannya, tentu memiliki beberapa karakteristik unit-unit dalam mengambil keputusan sebagai berikut: (a) Karakteristik sosio ekonomi, dimana masyarakat ini tergolong memiliki sebuah keteraturan melalui struktur sosial yang kental maupun kehidupannya yang bersifat tradisional dan kondisi ekonomi masyarakat yang pada umumnya sebagai petani dengan mengandalkan lahan maupun sebagai peternak, masyarakat pada umunya tidak mudah menerima suatu informasi yang dianggap baru. (b) Variabel bersifat kepribadian yaitu apatis adalah salah satu sifat yang dimiliki masyarakat, dimana 
mereka akan menyesuaikan tiap kebaruan informasi yang didapat jika relevan terhadap aturan atau hal-hal yang berlaku dan dipercayai. (c) Perilaku komunikasi masyarakat perbatasan verbal selalu menyesuaikan dengan nilainilai yang berlaku, masyarakat ini memiliki kebiasaan tidak dengan gampang menyerap suatu informasi baru atau inovasi, mereka akan menunggu kepastian sesuai dengan arahan yang disampaikan oleh para pemuka adat maupun tokoh masyarakat yang dinilai lebih dipercaya oleh mereka.

Berdasarkan ketiga karakteristik di atas masyarakat masih sangat kental pemahaman budaya maupun nilai dan norma yang berlaku. Hal ini mengikat mereka sebagai aturan dalam hidup bersama di wilayah perbatasan bahkan dalam menerima suatu inovasi atau bentuk kebaruan informasi bagi mereka.

Pada tahapan Persuasi (Persuasion) adopter akan melakukan penyesuaian untuk memutuskan diterima atau ditolaknya suatu inovasi. Dalam tahapan ini terdapat setidaknya 5 karakteristik sebuah inovasi yang dibahas pada elemen inovasi seperti relative advantage, compatibility, complexity, triability, dan observability.

Tahapan atau fase ini, komunikasi yang dilakukan secara sosial oleh BPP Kabupaten Kupang untuk menyebarluaskan informasi tak begitu sulit untuk diterima atau dipahami secara baik oleh masyarakat, dikarenakan salah satu faktornya yaitu agent of change dari BPP kabupaten Kupang dan merupakan kepala dinasnya adalah anak asli dari daerah Amfoang sehingga tidak mempersulit jalinan komunikasi. Namun berkaitan dengan kesepakatan menjadikan treaty 1904 sebagai landasan penentuan titik batas negara, melalui mediasi oleh BPPD Kabupaten Kupang mendapat penolakan secara berlanjut karena dinilai tidak adanya kesusuaian dengan sejarah yang mereka pegang selama ini.

Selanjutnya, Tahap Pengambilan Keputusan. pada fase ini penerima informasi akan mulai melakukan tindakan mengambil keputusan untuk menerima maupun menolak suatu informasi atau inovasi. Dalam fase ini terdapat beberapa faktor yang menjadi tolak ukur terhadap proses pengambilan keputusan terhadap sebuah inovasi, yakni:

Pertama yaitu praktik atau kejadian sebelumnya, dimana setelah peristiwa terpisahnya wilayah Timor Timur tahun 1999 dan kemudian berdiri menjadi sebuah negara sendiri, merupakan babak hidup baru bagi masyarakat perbatasan di Amfoang. Dimana mereka dulu hidup berdampingan dan kemudian terpisah. Kesepakatan mengenai treaty tahun 1904 sebagai landasan titik batas menimbulkan persepsi arti bagi wilayah yang diolah bersama sejak dulu.

Perjanjian treaty tahun 1904 sendiri adalah kesepakatan yang diterapkan para penjajah, tapi hal ini berbeda jika dilihat dari sudut pandang budaya bagi masyarakat Netemnanu Utara yang menilai kesepakatan tersebut sebagai hasil perjanjian zaman penjajahan dan jika diterapkan sekarang menjadi sebuah inovasi dengan terpisahnya kedua masyarakat dan hal ini dinilai tidak relevan dengan pemahaman sejarah masyarakat Netemnanau Utara.

Kedua Perasaan akan adanya kebutuhan. Persoalan tapal batas wilayah Naktuka, menjadi fenomena yang terus menimbulkan pertanyaan bagi masyarakat Netemnanu Utara. Masyarakat membutuhkan jawaban atau penjelasan yang pasti namun sesuai dengan harapan masyarakat dalam menyelesaikan permasalahan yang terus berlarut-larut tersebut.

Ketiga yaitu keinovatifan, pada umumnya masyarakat yang hidup dan aksesnya masih cukup sulit atau belum terlalu terkontaminasi dengan suatu keinovasian teknologi secara menyeluruh, masih sangat menganut paham tradisionalisme seperti halnya masyarakat Netemananu Utara. Masyarakat masih sangat bergantung pada arahan atau pandangan pemangku adat maupun tokoh masyarakat dalam bertindak atau mengambil keputusan.

Keempat yaitu norma dalam sistem sosial. secara keseluruhan masyarakat di wilayah perbatasan masih sangat merealisasikan nilai atau norma dalam sistem kehidupan sosial yang mereka jalani. Hal ini paten dan sangat kental pengaruhnya bagi masyarakat, oleh karena itu masyarakat juga akan lebih menghargai pendapat para pemangku adat ketimbang aparatur desa, sehingga dalam pengambilan keputusan terhadap suatu informasi baru atau inovasi baik itu diterima maupun ditolak tanpa adanya unsur paksaan, masih sangat terarah di bawah pengaruh para pemangku adat.

Berkaitan dengan penyebaran informasi atas kesepakatan perjanjian traktat 1904 secara komunikasi sosial oleh pemerintah langsung 
mendapat penolakan dari pemangku adat sehingga hal ini menyebabkan penolakan secara berlanjut oleh masyarakat. Tentu saja dikarenakan masyarakat dan para tokoh adat merasa adanya ketidaksesuaian dengan nilai atau norma dalam sistem sosial yang mereka paham selama ini secara budaya, terkait sejarah batas wilayah kedua negara berdasarkan area zona bebas Naktuka. Keputusan ini diberlakukan secara kolektif, dimana keputusan diambil oleh karena kesepakatan bersama antara pihak tokoh adat yang membicarakannya dengan perwakilan masyarakat tertentu dalam pertemuan tersebut meski sudah jelas mereka semua sepakat menolak informasi tersebut.

Berdasarkan uraian ketiga fase atau tahapan di atas, dapat diketahui bahwa masyarakat terus melakukan penolakan untuk mengikuti kesepakatan perjanjian traktat 1904 karena hal ini tidak sesuai dengan pemahaman masyarakat secara kuat dalam sistem sosial yang berlaku dan para pemangku adat sebagai opinion leader juga memberi kontribusi terhadap penolakan sehingga informasi tersebut tidak diterima oleh masyarakat Netemnanu Utara.

Menurut Rogers, tahap atau bagian pelaksanaan serta tahapan konfirmasi, dapat diimplementasikan jika pada tahapan sebelumnya seperti tahap pengambilan keputusan dimana si penerima informasi atau adopter mengadopsi kebaruan informasi sebagai bentuk inovasi yang disebarluaskan, mengenai penyebarluasan suatu informasi mengenai treaty 1904 oleh pemerintah melalui komunikasi sosial hanya berlangsung dalam tiga tahap sedangkan kedua tahap selanjutnya tidak dapat diberlakukan karena masyarakat beserta para pemangku adat yang menolak informasi yang dianggap baru tersebut. Sehingga kebaruan informasi tersebut tidak dapat diimplementasikan karena masyarakat yang terus melakukan penolakan.

Karakteristik masyarakat Netemnanu Utara dalam menerima inovasi atau kebaruan informasi. Pada dasarnya dalam sebuah sistem sosial masyarakat digolongkan ke dalam beberapa kategori sebagai adopter suatu inovasi, yang biasanya akan disesuaikan dengan tingkat keinovatifan atau kecepatan menerima suatu inovasi.

Adapun pengelompokan yang sering menjadi rujukan sesuai kelompok kurva pengadopsian yang diuji oleh pencetus teori yaitu
Roggers dibagi sebagai berikut: Innovators: Sekitar $2,5 \%$ pada kateogi ini individu yang pertama kali melakukan pengadopsian suatu inovasi, Early Adopters (Perintis/Pelopor): $13,5 \%$ yaitu para perintis yang menerima suatu inovasi, Early Majority (pengikut Dini): $34 \%$ pengikut awal dari sebuah inovasi, Late Majority (pengikut Akhir): $34 \%$ pengikut diposisi terakhir dalam menerima inovasi, Laggards (Kelompok Kolot/Tradisional): 16\% terakhir adalah kaum tradisional atau masih dianggap kolot terhadap suatu inovasi.

Berdasarkan uraian kurva adopsi oleh Roggers dan sesuai dengan konteks adopsi informasi kesepakatan mengenai treaty 1904 sebagai landasan penentuan batas wilayah oleh pemerintah dari pusat kemudian dimediasi atau diwadahi oleh Badan Pengelola Perbatasan Daerah Kabupaten Kupang kepada masyarakat Netemnanu Utara Kecamatan Amfoang Timur, sesuai kesepakatan masyarakat bersama tokoh adat langsung mendapatkan penolakan atas informasi tersebut.

Sehingga berdasarkan data dari hasil Tanya jawab secara mendalam, dapat diketahui bahwa masyarakat perbatasan yang berada di Amfoang (RI) sebagai adopter Laggards dimana masyarakat ini sebenarnya masih sangat tradisional dengan menghargai budaya yang ada dan bukan tergolong kolot. Hal ini berdasarkan hasil pengumpulan data secara kualitatif melihat dari perbandingan wawancara mendalam yang peneliti lakukan dengan BPP Kabuapten Kupang dan Masyarakat Netemnanu Utara kecamatan Amfoang Timur, dimana adanya sistem nilai atau norma yang mereka paham berbeda dengan keputusan mengikuti perjanjian traktat 1904 berdasarkan sejarah atau budaya selama ini, masyarakat perbatasan menanggapi kesepakatan traktat 1904 secara tradisional atau dalam artian bukan kolot melainkan menganggap informasi yang disampaikan tidak compatible atau tidak sesuai dengan pemahaman budaya yang berlaku sehingga masyarakat menolak informasi tersebut. Karena itu dianggap sebagai salah satu cela kesuksesan bagi pihak Timor Leste dan ketidakjelian pemerintah, akibat kurangnya keterlibatan masyarakat maupun komunikasi antar pihak pemerintah pusat dengan masyarakat terkait penyelesaian konflik wilayah batas area zona bebas Naktuka.

Komunikasi secara sosial merupakan satu- 
satunya media yang digunakan untuk mencapai kesepahaman antara kedua belah pihak dalam menyampaikan kebaruan informasi maupun terkait kegiatan yang akan dilaksanakan di wilayah perbatasan. Pemerintah daerah yaitu BPP Kabupaten Kupang menggunakan komunikasi secara sosial dalam berkomunikasi dengan masyarakat perbatasan, sehingga dalam proses komunikasi mengandung unsur-unsur sosial budaya yang menjadi bagian hidup dari masyarakat dan suasana yang sering dibangun bersifat keakraban dimana terjalinnya komunikasi dua arah secara tatap muka yang sering dianggap etis atau sesuai kebiasaan masyarakat perbatasan, kemudian penerima informasi yaitu masyarakat perbatasan dapat langsung memaknai atau memahami serta memberikan respons kepada pemerintah dalam mencapai integrasi makna, sehingga bentuk komunikasi sosial ini dapat menjadi rujukan dalam pencapaian integrasi sosial di wilayah manapun di Indonesia demi tercapainya stabilitas sosial, baik itu di tingkat lokal maupun nasional yang mengarah pada pembangunan nasional yang lebih baik.

\section{SIMPULAN}

Jenis komunikasi yang dilakukan adalah komunikasi sosial langsung, atau biasa disebut komunikasi tatap muka (face to face) yaitu proses komunikasi secara sosial untuk menyebarkan atau menyampaikan informasi melalui pertemuan secara langsung dengan masyarakat wilayah Netemnanu Utara, dan komunikasi secara bebas (non organik) tidak menjadikan formalitas sebagai hal yang harus dipatuhi, satu-satunya yang menajadi acuan adalah kode atau nilai sosio-kultural. Setiap informasi disebarkan BPP Kabupaten Kupang tidak terikat secara formal namun lebih mengarah pada aturan sosio maupun kultral yang selama ini berlaku pada masyarakat.

Adapun proses komunikasi sosial dalam penyebaran informasi dimulai dari adanya pertemuan antara pihak BPP Kabupaten Kupang sebagai agent of change dengan tokoh adat dan selanjutnya para tokoh adat mengumpulkan masyarakat di balai pertemuan, kemudian diadakan pertemuan antara masyarakat dan pemerintah dengan menggunakan jalur komunikasi sosial secara interpesonal, selanjutnya disampaikan kebaruan informasi untuk menjadikan treaty 1904 sebagai landasan pengukuran batas Naktuka yang gagal karena mendapat penolakan saat itu juga oleh masyarakat. Hal ini dikarenakan tidak adanya komunikasi maupun keterlibatan masyarakat sebelumnya dalam penetapan keputusan, serta anggapan tidak adanya kesesuaian atau compatibility dengan sistem norma atau sejarah hidup masyarakat Netemnanu Utara Amfoang Timur.

Tahap penerimaan inovasi atau kebaruan informasi oleh masyarakat, terkait mengikuti perjanjian traktat 1904 hanya berlangsung dalam 3 tahap yaitu pengetahuan, persuasi dan tahap pengambilan keputusan. Tahap implementasi dan konfirmasi dari kebaruan informasi mengikuti perjanjian traktat 1904 yang disampaikan kepada masyarakat Netemnanu Utara tidak dapat berlanjut, masyarakat menilai minimnya pengetahuan pemerintah, tidak pernah melibatkan dan mengkomunikasikan hal ini dengan masyarakat serta kesepakatan tersebut bertentangan dengan unsur budaya masyarakat perbatasan, sehingga pada fase pengambilan keputusan masyarakat melakukan penolakan terhadap keputusan tersebut.

Karakteristik dari masyarakat Netemnanu Utara, penerima kebaruan informasi terkait persoalan area zona bebas Naktuka di wilayah perbatasan, terkait kesepakatan perjanjian traktat 1904 yang dikomunikasikan secara sosial oleh pemerintah pusat melalu mediasi BPP Kabupaten Kupang-Nusa Tenggara Timur dikategorikan sebagai kelompok Laggards. Hal ini bukan berarti masyarakat dikategorikan kolot, tapi masyarakat memiliki nilai tradisi atau sejarah terkait wilayah perbatasan Naktuka yang menjadi konflik di wilayah perbatasan antara Indonesia dan Timor Leste, sehingga terjadi penolakan terhadap kebaruan informasi yang disampaikan pemerintah.

Saran, pemerintah pusat maupun daerah sebaiknya selalu melibatkan masyarakat dalam pengambilan keputusan di setiap pertemuan yang berkaitan dengan batas wilayah antara kedua belah pihak negara, sebelum melakukan kesepakatan untuk menghindari komunikasi yang dilakukan gagal dan meminimalisir terjadinya konflik. 


\section{DAFTAR PUSTAKA}

Annur, M. A. (2013). Difusi dan adopsi inovasi penanggulangan kemiskinan (studi difusi dan adopsi inovasi dalam layanan "mbela wong cilik" unit pelayanan terpadu penanggulangan kemiskinan (uptpk) di Kabupaten Sragen). Journal of Rural and Development, Vol IV No.

1. Retrieve from https://jurnal.uns. ac.id/rural-and-development/article/ download/23384/17064.

Biliocta, Y. (2016, May 12). Timor Leste serobot lahan di naktuka, warga geram dan ancam Perang. Diambil dari: https:// www.merdeka.com/peristiwa/timor-lesteserobot-lahan-di-naktuka-warga-geramdan-ancam-perang.html

Creswell, W. (2007). Qualitatief inquiry and research design. London: New Delhi.

Gumilar, N. (2017). Dukungan kampanye militer terhadap diplomasi Indonesia di perbatasan darat Indonesia - Timor Leste. Jurnal Pertahanan \& Bela Negara, Volume 7 No 2. http://jurnal.idu.ac.id/index.php/ JPBH/article/view/212/111.

Hendropuspito. (1989). Sosiologi sistematik. Yogyakarta: Kanisius.

Kolne, Y. (2014). Implementasi perjanjian perbatasan RI-RDTL dalam upaya penyelesaian masalah perbatasan. Jurnal Ilmu Politik, vol. 5, no. 1, pp. 100-114. https://doi.org/10.14710/ politika.5.1.2014.100-114.

Kusumadewi, A. (2016). Tokoh adat cemas Naktuka di Kupang dicaplok Timor Leste. Retrieve from: https://www.cnnindonesia.com/ nasional/20160826144354-20-154019/ tokoh-adat-cemas-naktuka-di-kupangdicaplok-timor-leste.

Miles, B. \& Huberman, M. (1984). Analisis data kualitatif. terjemahan oleh Tjetjep Rohendi Rohidi. 1992. Jakarta: Universitas Indonesia.

Mutti, A. (2014). Kesepakatan batas darat RITimor Leste: sebuah kajian diplomasi perbatasan RI. Jurnal Penelitian Politik Volume 11 No. 1 21-38.: http://ejournal. politik.lipi.go.id/index.php/jpp/article/ view/429.

Raharjo, S. (2014). Analisis dan upaya penyelesaian konflik antara warga perbatasan Timor Tengah Utara, Indonesia dengan warga distrik oecussi, Timor Leste pada 2012-2013. Jurnal Pertahanan, Vol 4 (1). http://jurnal.idu.ac.id/index.php/JPBH/ article /view/327.

Rahman, A. \& Sjoraida, F, D. (2017). Strategi komunikasi pemerintah Kabupaten Subang menyosialisasikan gerakan pembangunan untuk rakyat infrastruktur berkelanjutan. Jurnal Kajian Komunikasi, Volume 5, No 2. http://jurnal.unpad.ac.id/jkk/article/ view/8443/711.

Rogers, E. M. (1995). Diffusion of innovation, 4 th ed. New York: The Free Press.

Setiaman, A. Sugiana, D. \& M, Narotama, M. (2013). Implementasi kebijakan keterbukaan informasi publik. Jurnal Kajian Komunikasi, Volume 1, No 2.http://jurnal.unpad.ac.id/jkk/article/ view/6044/3155.

Sugiyono. (2009). Metode penelitian kuantitatif, kualitatif dan $r \& d$, Bandung: Alfabeta.

Susanto, P. (1985). Komunikasi sosial di Indonesia. Bandung: Bina Cipta.

Utama, A. (2016). Tokoh adat NTT: Pemerintah lamban selesaikan sengketa naktuka. https://www.cnnindonesia.com/ nasional/20160909080018-20-157176/ tokoh-adat-ntt-pemerintah-lambanselesaikan-sengketa-naktuka.

Wani, A. H. (2011). Understanding conflict resolution. International Journal of Humanities and Social Science Vol. 1 No. 2. : http://www.ijhssnet.com/journals/ Vol._1_No.2;_February_2011/14.pdf.

Warga Timor Leste Duduki Naktuka, Masyarakat NTT Siap Perang. (2016, May 13). Retrieve from https://www.liputan6. $\mathrm{com} / \mathrm{regional} / \mathrm{read} / 2506103 /$ warga-timorleste-duduki-naktuka-masyarakat-ntt-siapperang. 